SHORT COMMUNICATION

\title{
HOMEOLOGOUS PROTEINS SYNTHESIS CONTROLLED BY HOMEOLOGOUS CHROMOSOMES IN WHEAT
}

\author{
F. García-Olmido and Pil.ar Cakbontho \\ Instituto Nacional de Investigacioncs Agronomicas, Madrict-3, Sjpain
}

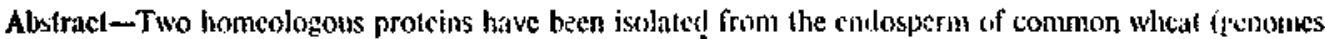

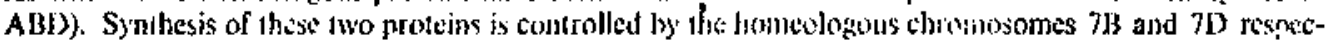
tively. However, Aegitops spethoid's, the more generally accepted B genome donor, does not sy'nthesilu, the $7 \mathrm{~B}$ protein.
\end{abstract}

WE HAVE previously described two sets of homeologous biochemical systems in wheat: the $\beta$-siiosterol esters systerns ' and the purothionins. ${ }^{2}$ In both cases cach homeolo: ous system was regulated by a different genome, hut we were unable to show which particular chronosomes were involved. We now report a patir of homeologous protcins from Triticam aestiam L. cindosperm whose synthesis is controlled by homeologous chomosomes.

An electrophoretic component (Fig. 1, CMI) of the chloroform-methanol $(2: 1, \mathrm{v} / \mathrm{v})$ extracted proteins from the endosperm of $T$, acstim $\mathrm{L}$. bas been used to detect this wheat in mixtures with $T$. durum Desf. ${ }^{3}$ Estimation of the amount of common wheat present wits achicved by densitometric measurement of the ratio between CMI and a second compronent (CM2) present in both wheat specics. We have now puritied these two compunents. A mol. wt. of 17,000 was obtained for $C M J$ and CM2 after reduction and denaturition by the method of Shapiro et al. The unreduced protcins gave a mol. wt. of 22,600-23,000 both by the above method and by Sephadex G-100 chromatomaphy. Further chemical cridence of the close relationship between $C M I$ and $C M 2$ was obiained by finger-fointing tryptic disich of CM2 from T. dertm, CMI and CM1 plus CM2 hom T, aestutm : llowing the thin-layer teclunique of Ballicux ot al. ${ }^{\mathrm{s}}$

ln order to investigate which cluromosomes control the synthesis of $\mathrm{CM} 1$ and $\mathrm{CM}$, half kernels of the monosomic and ditelocentric series of Chinese Spring wheat wete anitysed. Results are summarized in Fig. 1. Ahout cipal anounts of $\mathrm{CM} 1$ and $\mathrm{CM} 2$ are syinhesized in Chinese Spring. Monosomics $2 \Lambda$ and $7 D$ shuwed a decreassd proportion of $C M I$ and only mono $7 \mathrm{~h}$ a depression of CM2. No synthesis or CNI was observed in a ditelo 7ly and

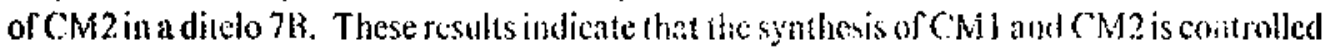

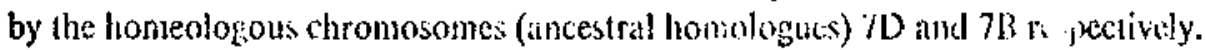

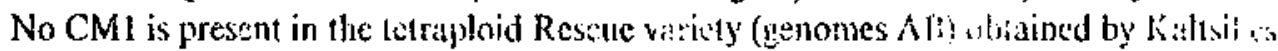
et al. ${ }^{6}$ by extraction of the D genome from hexaploid Rescue (genentes $A B D$ ) whinh de $\mathrm{s}$

'I. Gakcia-Oentil)o, Nonture 220, 114 (106)

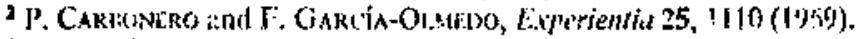

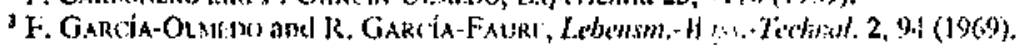

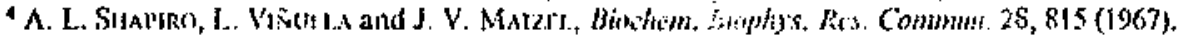

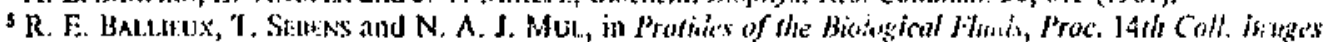
(citited by H. Preters), p. 527, Eksevier, Amsterdam (1M67).

6. J. Kaltsikes, 1., E. Fyans and W. Busiak, Sciemf 159, 211 (1908). 
synthesize this protein. A synthetic $T$. spelat (ABD) shows the normal T. aestirum 1. pattern and its parental species $T$. carthicum (AB) and Aegilops squarrosa (D) show CM2 and CM1 respectively. However, CM2 was not found either in Ae. speltoides (B) or the symthetic AB alloploids Ae. speltoides $\times$ T. monococcum-TA396 and Ac.spelloides $\times$ T.aegilopoides-TA398 obtained by R. Riley. This fact, as well as ofher biochemical evidence, ${ }^{7}$ secms to indicate that either the B genome donor of wheat was not exactly Ac. spcltoids's or that the genome has been extensively modified after the tetraploid was formed.

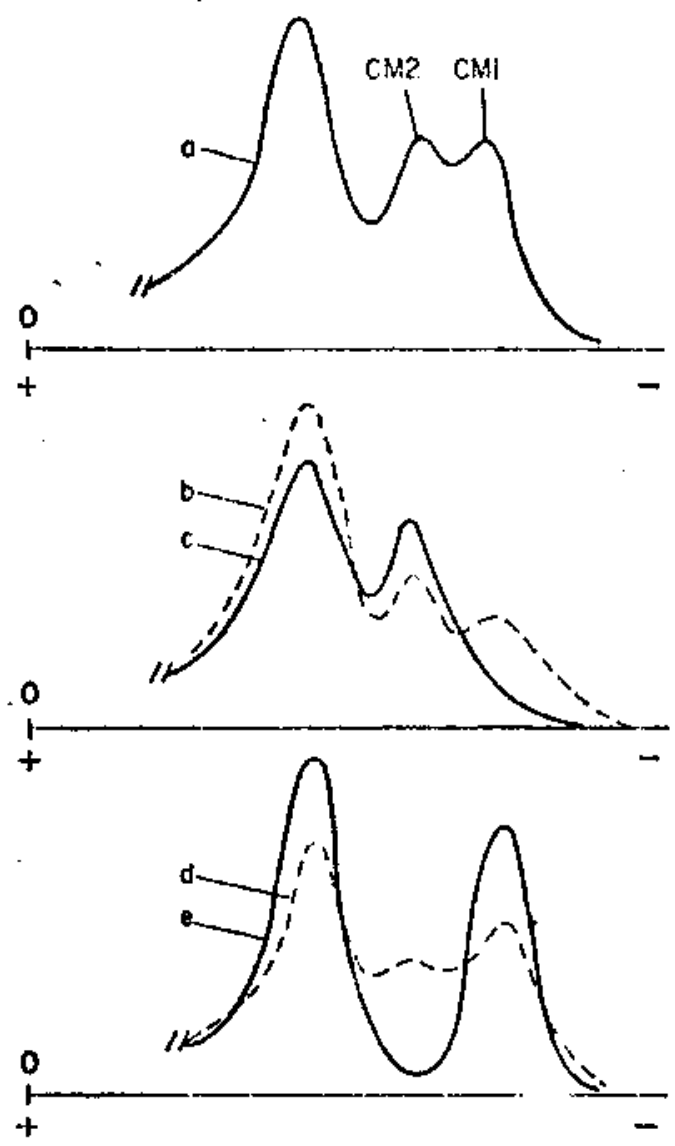

Fio, 1. Densitograms of proteins CMl anj CM2 siliaratto by tirfa slakchagel fi.ectro-

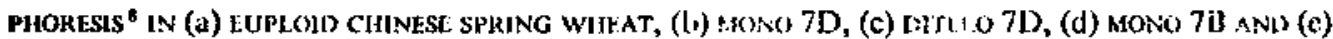
DITLLOO 7B.

\section{EXPERIMLNTAL}

\section{Purification of Proteins CM1 and CM2}

Flour was defated with petroletm ether and the protein exfracted with $\mathrm{CHCl}_{1}-\mathrm{M} \mathrm{LOH}(2: 1, \mathrm{v} / \mathrm{v})$ as previously described." 'The extracted protein ( 10 ga) was dissolved in $3 \mathrm{M}$ urei ( $150 \mathrm{ml})$. Most of the prolein was precipitated first by addition of $0.1 \mathrm{p} / \mathrm{NaCl}(50 \mathrm{ml})$ and then by dialysis against the same solution. The clear supcriatant was fractionated by sulling out with $\left(\mathrm{NH}_{4}\right)_{2} \mathrm{SO}_{4}$. Fli: Isuphoretically pure CMI was

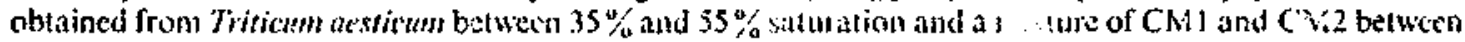

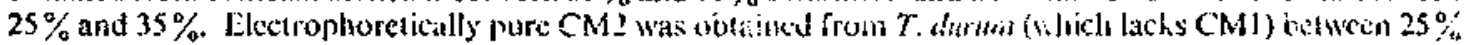
and $35 \%$ saturation. Urea starch-bel elictiophoress of fractions was perforined afice each purificating stip by tise method of Woychik at at. ${ }^{\mathrm{s}}$

TF. Garcia-Olmono, All. Anla Dei 9, 245 (1969).

-J. H. Woychik, J. A. Bouvm and R. J. Dimler, wh. Bivehem. Biophy.. 9.5, 477 (1961). 